\title{
REPRESENTASI PEREMPUAN SEBAGAI SIMBOL PERLAWANAN \\ PADA NOVEL JALAN PANJANG MENUJU PULANG KARYA PIPIET SENJA: KAJIAN FEMINISME RADIKAL
}

\author{
THE REPRESENTATION OF WOMEN RESISTANCE SYMBOLIS \\ IN PIPIET SENJA'S JALAN PANJANG MENUJU PULANG: \\ THE STUDY OF RADICAL FEMINISM
}

\author{
Suci Annisa Caroline ${ }^{1}$, Novi Anoegrajekti², Heru S.P. Saputra ${ }^{3 *}$ \\ ${ }^{1}$ Alumni Fakultas Ilmu Budaya, Universitas Jember \\ ${ }^{2,3}$ Fakultas Ilmu Budaya, Universitas Jember \\ *Corresponding Author: heruespe@gmail.com \\ Informasi Artikel:
}

Dikirim: 7/02/2019 ; Direvisi: 14/03/2019; Diterima: 11/04/2019

\begin{abstract}
In a dominant patriarchal culture, women are considered lower than men in many aspects such as education, politics, workplace, and the sexuality discourse. This article shows the representation of women who symbolize her resistance which is reflected in the novel entitled Jalan Panjang Menuju Pulang by Pipiet Senja. It is used qualitative method supported by descriptive analysis on the basis of theoretical of radical feminism. The results of the study show that woman (Fatin) is subjugated by men. There are physical violence, psychological violence, and also domestic violence which happened to Fatin. Hans did Sexual harassment, while sexual violence done by Frankie. Meanwhile her husband, Rimbong, threat her and hit her. Fatin suffers psychic and also physical violence. This spouse fought for the custody right. This research discuss about how Fatin showing her resistance to the domestic violence and sexual violence. In her apartment, Fatin dares to scuffles then reports Frankie to the police. She also reveals her resistance by hiding away her child when her husband will take her child.
\end{abstract}

Keywords: domestic violence, physical violence, psychic violence, radical feminism

\begin{abstract}
Abstrak
Fenomena dalam masyarakat yang dominan budaya patriarki, perempuan dinilai lebih rendah dibandingkan laki-laki, baik dalam konteks pendidikan, politik, dunia kerja, maupun wacana seksualitas. Penelitian ini bertujuan untuk mendeskripsikan representasi perempuan sebagai simbol perlawanan yang terefleksi dalam novel Jalan Panjang Menuju Pulang karya Pipiet Senja. Metode penelitian menggunakan metode kualitatif, dengan analisis deskriptif atas dasar konsep teoretik feminisme radikal. Hasil kajian menunjukkan bahwa terdapat dominasi laki-laki terhadap perempuan dalam novel Jalan Panjang Mепијu Pulang, yakni berupa kekerasan fisik, kekerasan psikis, dan kekerasan dalam rumah tangga (KDRT). Kekerasan fisik berupa pelecehan seksual dialami tokoh Fatin akibat ulah tokoh Hans, sedangkan kekerasan seksual dialami Fatin akibat ulah tokoh Frankie. Kekerasan psikis dirasakan Fatin akibat ancaman suaminya, Rimbong, atas perebutan anak mereka. KDRT dialami Fatin atas pemukulan yang dilakukan Rimbong terkait persoalan perebutan anak mereka. Representasi yang menyiratkan makna dan ideologi sebagai simbol perlawanan atau resistensi kaum tertindas atas segala penindasan
\end{abstract}


Representasi Perempuan sebagai Simbol Perlawanan pada Novel Jalan Panjang Menuju Pulang Karya Pipiet Senja: Kajian Feminisme Radikal (Suci Annisa Caroline, Novi Anoegrajekti, Heru S.P. Saputra)

atau penjajahan dilakukan oleh Fatin. Ia melakukan resistensi terhadap kekerasan seksual dan KDRT. Resistensi terhadap kekerasan seksual dilakukan Fatin yakni melakukan perlawanan dalam peristiwa di apartemen dan dapat melaporkan Frankie kepada pihak kepolisian untuk mendapatkan hukuman setimpal. Resistensi terhadap KDRT dilakukan Fatin dengan cara melawan kepada suaminya dan membawa lari anaknya agar berada dalam kekuasaannya.

Kata kunci: feminisme radikal, kekerasan fisik, kekerasan psikis, kekerasan dalam rumah tangga

\section{PENDAHULUAN}

Perjalanan kehidupan sosial masih menyisakan persoalan dalam relasi laki-laki dan perempuan. Sebagai makhluk hidup, laki-laki dan perempuan memiliki wilayah yang dikategorikan sebagai kodrat, tetapi di sisi lain juga memiliki ranah konstruksi sosial. Wilayah kodrati terkait dengan ranah biologis manusia, sedangkan wilayah konstruksi terkait dengan ranah sosiologis, khususnya sebagai bagian dari kehidupan sosial yang senantiasa mengadakan kontak dan relasi sosial. Fenomena semacam itu tidak hanya ada dalam realitas sosial, tetapi juga terekam dalam karya-karya kreatif, termasuk dalam karya yang berupa novel.

Sudah banyak pengarang Indonesia yang mengekspresikan gagasannnya terkait tematik relasi laki-laki dan perempuan, baik yang mengungkapkan tentang harmoni maupun ketimpangan sosial dari relasi tersebut. Salah satu pengarang yang mengungkap ketimpangan relasi sosial laki-laki dan perempuan adalah Pipiet Senja. Pipiet Senja adalah nama pena Etty Hadiwati Arief, lahir di Sumedang, 16 Mei 1956, dari pasangan Hj. Siti Hadijah dan S.M. Arief (alm), seorang pejuang '45. Nama Pipiet Senja diambil dari kisah hidupnya yang menyukai senja. Setiap hari Pipiet Senja menghabiskan waktu di pinggiran sawah dengan melihat banyak burung pipit yang sedang berterbangan di kala senja.

Karya-karya Pipiet Senja berupa novel di antaranya adalah Biru yang Biru, Sepotong Hati di Sudut Kamar, Jalur Sutra Jalur Cinta, Namaku May Sarah, Meretas Ungu, Cahaya di Kalbuku, Jejak Cinta Sevilla, Cinta dalam Sujudku, Para Pencari Keadilan, Romansa 2 Benua, Dalam Semesta Cinta, Kalam-kalam Langit, dan Jalan Panjang Menuju Pulang. Karya-karya tersebut memuat beragam tematik yang menjadi bagian hidup pengarangnya. Karya yang disebutkan terkahir, yakni Jalan Panjang Menuju Pulang, semula berjudul Tuhan Jangan Tinggalkan Aku, yang mengisahkan perjuangan hidup seorang perempuan di hadapan laki-laki yang banyak memunculkan konflik. Perempuan yang menjadi tokoh utama, yakni Fatin, mengalami liku-liku hidup yang menegangkan, mengenaskan, tetapi juga menunjukkan betapa perjuangan hidup memerlukan pengorbanan yang maksimal. Dalam novel Jalan Panjang Menuju Pulang karya Pipiet Senja (2017) ditemukan tindak kekerasan yang dialami oleh tokoh Fatin.

Fenomena tersebut menjadi menarik untuk dikaji, khususnya terkait relasi laki-laki dan perempuan. Meskipun demikian, perlu juga menelusuri kajian-kajian terdahulu yang membahas Jalan Panjang Menuju Pulang, untuk mengintegrasikan sekaligus memposisikan kajian ini dalam konteks kajian-kajian sebelumnya tersebut. Dalam penelusuran pustaka, ditemukan beberapa kajian, di antaranya dilakukan oleh Khalilurrahman, Putri, Nurjahan, Rosliani, dan Resti.

Khalilurrahman (2017) memaparkan perjalanan hidup dalam novel yang menjadi 
refleksi dari realitas sosial dalam novel Jalan Panjang Menuju Pulang. Hal ini terkait dengan perjalanan tokoh Fatin yang berupaya untuk mencapai kebahagiaan hidup, dengan merantau ke Jakarta hingga mencapai tingkatan sosial yang diinginkannya. Di sisi lain, dalam kajiannya, Putri (2018) mendeskripsikan motivasi tokoh utama dalam novel tersebut, yakni upaya untuk mengangkat eksistensi dan memenuhi kebutuhan hidup manusia, baik kebutuhan penghargaan diri maupun aktualisasi diri. Hal tersebut dilakukan tokoh Fatin dalam kehidupan di tengah keluarganya.

Kajian Nurjahan (2018) mendeksirpsikan tanda-tanda simbolik dalam kehidupan tokoh Fatin, baik terkait ikon, indeks, maupun simbol. Kajian tersebut menyimpulkan bahwa simbol-simbol patriarki mendominasi kehidupan masyarakat pada umumnya, terermasuk yang dialami Fatin. Sementara itu, Rosliani (2018) memaparkan romantika kehidupan tokoh utama, yakni Fatin, dengan berbagai cobaan dan siksaan. Dirinya dapat dikatakan memiliki motivasi yang ambisius dalam rangka untuk memenuhi kebutuhan hidup dirinya dan keluarga. Di sisi lain, Resti (2019) mengungkap kekerasan terhadap perempuan dalam novel Jalan Panjang Menuju Pulang, di antaranya berupa cacian, hinaan, dan ancaman atas keselamatan hidup. Dalam kajian ini disimpulkan bahwa penyebab utama kekesaran adalah faktor sosial budaya, kondisi situasional, dan faktor ekonomi.

Meskipun kajian-kajian tersebut beragam tematik, persoalan yang substansial dapat digarisbawahi yakni pada persoalan relasi laki-laki dan perempuan. Untuk itu, sebagai kajian lanjutan dari kajian-kajian sebelumnya tersebut, kajian ini menekankan pada relasi sosial lakilaki dan perempuan, khususnya dalam konteks representasi perlawanan perempuan. Artinya, perempuan tidak hanya menjadi makhluk lemah yang hanya menerima tindakan laki-laki terhadap dirinya, tetapi juga mampu melakukan perlawanan atau resistensi. Perempuan menyadari bahwa ketika dirinya dirugikan karena persoalan gender, khususnya relasi seksualitas, mereka melakukan resistensi sesuai konteksnya.

Bertolak dari hal tersebut, persoalan yang kemudian muncul adalah bagaimana representasi perlawanan perempuan terhadap laki-laki yang tercermin dalam novel Jalan Panjang Menuju Pulang? Bagaimana strategi perempuan dalam menghadapi kekerasan lakilaki terhadap dirinya? Kedua persoalan tersebut menjadi persoalan utama yang dijawab dalam kajian ini.

Jika dikaitkan dalam konteks sosial zaman sekarang, budaya patriarki yang semakin marak di masyarakat membuat perempuan lebih rentan mendapatkan perbuatan tidak mengenakkan, berbagai kekerasan, salah satunya adalah kekerasan seksual. Kekerasan seksual merupakan tindakan yang bermaksud menyakiti secara seksual dengan berbagai cara, di antaranya memegang dan memaksa berhubungan seksual tanpa persetujuan dari pemilik tubuh dengan maksud menggapai kepuasan diri. Perempuan akan merasa tersinggung dengan tindakan kekerasan ini. Ia tidak hanya merasakan kerugian secara fisik, tetapi juga kerugian secara psikis. Dalam novel Jalan Panjang Menuju Pulang karya Pipiet Senja ditemukan tindak kekerasan yang dialami oleh tokoh perempuan. Kisah dalam novel tersebut sering ditemukan perbuatan laki-laki yang mendominasi kekerasan terhadap perempuan.

Bertolak dari paparan tersebut dan kajian yang relevan, dapat diketahui bahwa substansi novel dapat dicermati dengan perspektif feminisme. Perlawanan yang dilakukan perempuan untuk menyetarakan haknya disebut gerakan feminisme. Feminisme pada hakikatnya menginginkan perempuan dianggap sebagai makhluk otonom dan memiliki 
persamaan hak antara laki-laki dan perempuan di segala bidang, baik politik, ekonomi, pendidikan, hukum, maupun perlakuan masyarakat (Anoegrajekti, 2010:26).

Secara konseptual teoretik, feminisme memiliki beberapa aliran, yaitu feminisme liberal, feminisme radikal, feminisme marxis dan sosialis, feminisme psikoanalisis dan gender, feminisme eksistensialis, feminisme postmodern, feminisme multikutural dan global, dan ekofeminisme (Tong, 1998). Masing-masing konsep dan periode memiliki penekanan gerakan dan fokus yang berbeda, meskipun orientasinya bermuara pada hilir yang sama, yakni kesetaraan dan otonomi yang egaliter antara laki-laki dan perempuan. Mengingat kajian ini menekankan pada fokus kekerasan terhadap perempuan, khususnya terkait seksualitas, maka konsep yang digunakan adalah konsep feminisme radikal.

Sebagaimana digambarkan Tong (1998), feminisme liberal berusaha menyadarkan perempuan bahwa ia adalah kaum yang tertindas. Perempuan tidak dapat memiliki kebebasan seperti apa yang dilakukan laki-laki. Contoh yang paling terlihat dalam masyarakat yaitu ketidakadilan dalam pekerjaan yang membuat perempuan menjadi teralienasi. Menurut Tong (1998:2) masyarakat mempunyai keyakinan bahwa perempuan secara alamiah tidak sekuat dan secerdas laki-laki. Oleh karena itu, masyarakat meminggirkan perempuan dari akademi, forum, dan pasar. Feminisme liberal menekankan bahwa setiap individu mempunyai kebebasan mengakses pilihan-pilihan yang ada. Perempuan berhak bebas dan mendapat kesetaraan dengan laki-laki di berbagai bidang, misalnya bidang ekonomi dan politik.

Tong (1998:67-138) menjelaskan bahwa feminisme radikal menekankan pada seksualitas, lesbianisme, dan reproduksi serta kekuasan perempuan dan laki-laki. Alasan utamanya yaitu adanya sistem patriarki yang membuat penguasaan hubungan seksual didominasi oleh laki-laki. Penindasan utama dalam feminisme radikal adalah tubuh perempuan yang sering dijadikan objek oleh laki-laki. Sistem seks/gender menjadi penyebab fundamental dari opresi terhadap perempuan.

Bertolak dari hal tersebut, kajian terhadap novel Jalan Panjang Menuju Pulang ini menekankan pada upaya mengungkapkan penindasan yang dialami tokoh perempuan yang didasarkan seksualitas. Relasi laki-laki dan perempuan atas dasar seksualitas menjadi salah satu penyebab utama dominasi laki-laki terhadap perempuan.

\section{METODE}

Metode yang digunakan dalam penelitian ini adalah metode kualitatif dengan orientasi berupa penafsiran atas teks sastra. Dalam konteks kajian sastra, metode kualitatif diimplementasikan dalam pendekatan yang relevan, di antaranya pendekatan mimetik (Abrams, 1981). Dalam konteks ini, pendekatan mimetik memiliki asumsi dasar bahwa karya sastra merupakan mimesis atau cerminan dari realitas sosial. Hal ini terkait dengan eksistensi pengarang sebagai subjek individual yang tidak dapat dipisahkan dari subjek kolektif atau masyarakat di lingkungan sosial kehidupan pengarang.

Sumber data berupa novel, yakni novel Jalan Panjang Menuju Pulang karya Pipiet Senja yang diterbitkan oleh Penerbit Republika pada tahun 2017. Satuan analisis berupa pernyataan-pernyataan yang terkait dengan fenomena relasi laki-laki dan perempuan, khususnya persoalan dominasi laki-laki terhadap perempuan dan resistensi perempuan terhadap laki-laki. Perwujudan dominasi tersebut dapat berupa kekerasan fisik, kekerasan psikis, atau kekerasan dalam rumah tangga (KDRT), sedangkan resistensi berupa perlawanan 
terhadap bentuk-bentuk kekerasan tersebut. Dengan demikian, satuan analisis dalam penelitian ini dapat berupa kalimat, paragraf, atau wacana yang terkait dengan kekerasan fisik, kekerasan psikis, dan KDRT, serta resistensinya.

Teknik pengumpulan data berupa pembacaan secara berulang dan mendalam terhadap novel Jalan Panjang Menuju Pulang guna memahami substansi cerita, untuk menemukan satuan analisis berupa kalimat, paragraf, atau wacana yang mencerminkan dominasi laki-laki terhadap perempuan dan resistensi perempuan terhadap laki-laki, khususnya terkait dengan kekerasan. Data yang didapat dari novel, kemudian dilakukan klasifikasi atas dasar konsep kekerasan fisik, kekerasan psikis, dan KDRT. Kekerasan fisik dapat berupa pelecehan seksual dan kekerasan seksual. Di sisi lain, dengan bertolak dari konsep teoretik feminisme radikal, maka juga dikumpulkan data berupa kalimat, paragraf, atau wacana yang mencerminkan resistensi perempuan kepada laki-laki.

Analisis data dilakukan dengan cara menginterpretasi atau menafsirkan data untuk menemukan makna. Interpretasi didasari oleh konsep teoretik feminisme radikal. Interpretasi tersebut tidak dapat menafikan bahwa teks sastra sebagai fakta sastra merupakan mimesis dari fakta atau realitas sosial. Dengan demikian, pemaknaan atas data berupa teks sastra menjadi refleksi atas pemaknaan terhadap fenomena fakta sosial yang diekspresikan oleh Pipie Senja melalui novel Jalan Panjang Menuju Pulang. Hasil analisis berupa pernyataan-pernyataan yang merepresentasikan makna teks sastra sebagai feleksi dari makna realitas sosial, khususnya dalam ranah dominasi laki-laki atas perempuan dan resistensi perempuan terhadap laki-laki.

\section{HASIL DAN PEMBAHASAN}

Hasil dan pembahasan dalam penelitian ini dipaparkan dengan menekankan pada dominasi laki-laki terhadap perempuan dan resistensi perempuan terhadap laki-laki. Dominasi laki-laki terhadap perempuan diformulasikan menjadi tiga bagian, yakni kekerasan fisik, kekerasan psikis, dan KDRT, sedangkan resistensi perempuan terhadap laki-laki mencakup dua bagian, yakni resistensi terhadap KDRT dan resistensi terhadap kekerasan seksual.

\section{Dominasi Laki-laki}

Dominasi laki-laki terhadap perempuan dalam novel Jalan Panjang Menuju Pulang dilakukan oleh para tokoh lelaki, di antaranya dilakukan oleh Frankie, Rimbong, dan Hans terhadap tokoh perempuan, Fatin. Dominasi tersebut berupa kekerasan fisik, kekerasan psikis, dan KDRT.

\section{Kekerasan Fisik}

Kekerasan fisik dalam novel Jalan Panjang Menuju Pulang (JPMP) dialami oleh Fatin di apartemen Frankie, di Belanda. Fatin mengenal Frankie melalui media sosial, ketika melakukan transaksi dengan chatt terkait pembelian mutiara khas Lombok. Fatin berjualan mutiara di Lombok Barat, setelah sebelumnya terjadi cekcok dengan suaminya, Rimbong, yang tinggal di Jakarta. Dalam perkenalannya dengan Frankie, setelah mendapat bujuk rayu, akhirnya Fatin menyetujui untuk tinggal di apartemen milik Frankie di Belanda. Perkenalan dengan awal yang baik tersebut, ternyata berubah, dan Fatin diperlakukan secara tidak wajar oleh Frankie. Setiap hari Fatin mendapat kekerasan fisik dari Frankie. Jika Fatin melawan, 
amarah Frankie akan semakin tinggi. Frankie adalah laki-laki yang memiliki psikologi terganggu, karena memiliki masa lalu yang buruk sehingga ia sering melampiaskan kepada Fatin. Frankie bercerita bahwa sejak kecil ia diperlakukan tidak wajar oleh kakek tirinya. Kakek kandung Frankie meninggal ditembak tentara militer dari Jawa. Setiap Frankie mendengar kata "orang Jawa", ia membenci dengan apa pun yang berhubungan dengan Jawa. Fatin yang mendengarkan Frankie bercerita tersebut memberi pendapat bahwa semua bukanlah kesalahan orang Jawa. Frankie langsung marah dan memukul Fatin karena telah menyangkal pembicaraannya. Fatin disiksa dan dicaci maki oleh Frankie. Permintaan maafnya tidak membuat Frankie berhenti menyiksa. Ia terus menyiksa Fatin sampai merasa puas.

"Perempuan sinting!"

Lelaki itu meloncat ke arahnya sambil meraung hebat.

"Dasar, perempuan tidak tahu diri!"

Plaaak!

"Sudah diperlakukan baik-baik juga, huh!"

Buuug!

"He, dengar ya, aku ini sebenarnya sayang sekali kepadamu."

Deesss!

"Sayang, sayang, tahukah kamu sayang?"

Jegheeer!

"Tapi kamu ini liar, tidak tahu malu, tidak tahu diri!"

Braaak!

Lelaki itu sungguh telah menjelma iblis yang bangkit dari dasar neraka. Ia meracau sambil menghajar Fatin secara brutal (JPMP:139—140).

Kutipan data tersebut menunjukkan betapa kejam peristiwa yang dialami oleh Fatin, yang dilakukan oleh Frankie. Fatin baru menyadari bahwa tidak semua yang dikenalnya dengan awal baik akan senatiasa baik. Kejadian semacam itu membuat Fatin ingat dan kemudian bersandar kepada Sang Pencipta. Ia ingin shalat dan memohon ampun atas kesalahan yang selama ini dilakukannya. Saat Fatin mengambil wudhu, masih saja ia diperlakukan kasar oleh Frankie. Fatin dipukul Frankie dari belakang. Frankie tidak menyukai jika ada orang yang menyembah Tuhan. Ia meludahi Fatin yang sedang berwudhu. Fatin mencoba melakukan perlawanan dengan melempar benda sekitarnya ke arah Frankie, namun Frankie berhasil menghindarinya. Frankie semakin marah jika ia dilawan. Peristiwa dalam kisah ini menjadi gambaran betapa posisi perempuan menjadi lemah karena dominasi lakilaki.

Kekerasan fisik yang dirasakan Fatin juga menyangkut kekerasan seksual dan pelecehan seksual. Kekerasan seksual adalah semua perilaku atau tindakan merugikan perempuan yang berhubungan dengan seksualitas. Seseorang yang melakukan pemaksaan hubungan seksual secara paksa tanpa kerelaan dari yang bersangkutan disebut perkosaan (Fakih, 2001:18). Perilaku seperti ini biasanya dialami oleh perempuan karena memiliki daya tarik bagi laki-laki untuk melakukan hubungan seksual. Kekerasan seksual dialami oleh Fatin dalam kehidupannya di apartemen bersama Frankie. Fatin dipaksa untuk melayani dan memuaskan nafsu kebinatangan Frankie. Sementara itu, pelecehan seksual, sebagaimana disebutkan oleh Fakih (2001:20) juga menjadi bagian dari kekerasan. Pelecehan seksual yang 
dialami oleh Fatin berupa sentuhan, ucapan, dan percakapan online, yang menyinggung persoalan seksualitas dan menjadikan Fatin sebagai objeknya.

\section{Kekerasan Psikis}

Kekerasan psikis dalam novel Jalan Panjang Menuju Pulang (JPMP) dialami oleh Fatin dalam relasinya dengan Frankie dan Rimbong. Dalam relasinya dengan Frankie, Fatin bukan hanya menjadi korban kekerasan fisik, melainkan juga kekerasan psikis. Pertemanannya melalui media sosial yang berawal dengan hubungan baik, menjadi berubah ketika keduanya tinggal bersama di apartemen. Frankie memaksakan kehendak untuk dilayani kebutuhan seksnya, sedangkan Fatin menolak karena bukan suami-istri. Kekerasan psikis dialami Fatin berupa ancaman pembunuhan terhadap anak Fatin, Ridho, ketika Fatin menolak ajakan Frankie untuk berhubungan badan. Ancaman dengan tujuan yang sama tetapi menggunakan pola-pola yang beragam dan hal itu dilakukan secara berulang, mengakibatkan psikis Fatin traumatik. Akibatnya, ketika bertemu dengan lelaki, Fatin merasa khawatir dan ketakutan.

Kekerasan psikis juga dialami Fatin dalam relasi dengan suaminya, Rimbong. Fatin adalah istri kedua Rimbong. Istri pertama tidak memiliki anak, sehingga Rimbong memperistri Fatin dengan motivasi untuk memiliki anak, sebagai pewaris harta kekayaannya. Karena telah lama ditolong oleh Rimbong untuk menjadi pegawainya sehingga kehidupan ekonomi Fatin menjadi lebih makmur, maka Fatin bersedia untuk menjadi istri kedua Rimbong. Namun ketika anak mereka, Ridho, telah berusia dua tahun, muncul motivasi Rimbong untuk menguasai hak asuh anak. Fatin tidak menyetujui niat Rimbong, sehingga percekcokan pun tidak dapat dihindari.

Kamu ini tuli, keras kepala, atau memang dungu? Hah!"

Demikian hinaan, caci maki, pelecehan secara psikis yang semakin sering diterima Fatin dari lelaki itu. Bahkan beberapa kali Rimbong pun memperlihatkan gejala hendak memperlakukannya dengan tindak kekerasan.

"Apakah kamu ingin...." Lelaki itu hendak melayangkan tangan kekarnya. Wajahnya memerah bak kepiting rebus. Fatin tak tahan lagi menjerit ketakutan! (JPMP:89)

Data di atas menunjukkan tindak kekerasan psikis yang dilakukan Rimbong terhadap Fatin. Rimbong marah ketika datang ke Bungallow untuk mengambil Ridho, tetapi Fatin tidak segera menyerahkan anaknya tersebut. Rimbong pun melecehkan Fatin dengan berbagai hinaan, cacian, dan ancaman. Gambaran kekerasan psikis semacam itu menjadi refleksi dari realitas sosial bahwa posisi perempuan subordinat dan dibawah dominasi laki-laki.

\section{Kekerasan dalam Rumah Tangga}

Kekeradalan dalam rumah tangga (KDRT) merupakan tindakan kekerasan yang dilakukan oleh anggota keluarga kepada anggota keluarga yang lain dalam suatu rumah tangga, sehingga dapat berupa kekerasan fisik maupun psikis. Dalam masyarakat patriarkhi, KDRT pada umumnya dilakukian oleh laki-laki kepada perempuan, atau suami kepada istri. Kekerasan tersebut akibat dari berbagai persoalan, mulai dari persoalan ekonomi, sosial, tanggung jawab, kesetiaan, dan persoalan-persoalan kehesarian lainnya.

KDRT dalam novel Jalan Panjang Menuju Pulang dilakukan oleh Rimbong kepada 
Representasi Perempuan sebagai Simbol Perlawanan pada Novel Jalan Panjang Menuju Pulang Karya Pipiet Senja: Kajian Feminisme Radikal (Suci Annisa Caroline, Novi Anoegrajekti, Heru S.P. Saputra)

istrinya, Fatin. KDRT terjadi karena munculnya pengingkaran terhadap komitmen dalam rumah tangga. Sebagaimana diketahui, Rimbong memperistri Fatin karena dirinya tidak memiliki anak dari istri pertama. Namun, di sisi lain, Fatin bersedia diperistri dengan komitmen dapat hidup bersama dalam keluarga yang sakinah, mawadah, dan warohmah. Fatin tidak memuiliki bayangan bahwa dirinya hanya diperalat agar Rimbong dapat memiliki anak, yang kemudian diasuh secara pribadi untuk menjadi pewaris tunggal harta kekayaannya. Meskipun menjadi istri kedua, Fatin tetap menghendaki dapat hidup bersama dengan Rimbong, termasuk dalam mengasuh anak hingga dewasa. Namun, rupanya Rimbong tidak dapat memenuhi keinginan Fatin. Rimbong bersikukuh untuk menguasai hak asuh anak atas diri Ridho. Hal tersebut menjadi akar masalah yang tidak kunjung usai dan menjadi penyebab terjadinya KDRT. Data berikut menunjukkan hal tersebut.

"Di mana anakku hah?” Dengan tenaganya yang besar, Rimbong mendorong Fatin hingga tersungkur.

Fatin tidak menyahut, meskipun ancaman kekerasan sudah semakin nyata. "Berikan anakku, Fatin!” jerit Rimbong bagaikan singa kelaparan (JPMP:90).

Data tersebut memberi gambaran bahwa laki-laki masih lebih berkuasa atas perempuan dalam konteks kehidupan rumah tangga. KDRT menunjukkan lemahnya komitmen dalam membangun kondisi harmonis rumah tangga. Hal tersebut merefleksikkan posisi superordinat laki-laki dan subordinat perempuan. Dengan demikian, laki-laki masih mendominasi perempuan.

\section{Resistensi Perempuan}

Karakteristik masyarakat patriarki berimplikasi pada tindakan masing-masing individu yang mengikuti arus besar karakteristik masyarakat tersebut. Hal ini ditunjukkan banyaknya fenomena dominasi laki-laki terhadap perempuan. Meskipun demikian, perkembangan zaman berpengaruh pada cara pandang masyarakat, khususnya perempuan, dalam merespons fenomena sosial. Hal ini muncul dalam tindakan perempuan yang tidak pasif untuk menerima sebagai objek atau korban kekerasan, melainkan berupaya untuk melawannya. Resistensi perempuan terhadap laki-laki menjadi fenomena yang menggembirakan. Setidak-tidaknya, hal ini mencerminkan pandangan yang positif dari perempuan. Resistensi perempuan terhadap laki-laki dalam novel Jalan Panjang Menuju Pulang mencakup resistensi terhadap KDRT dan resistensi terhadap kekerasan seksual. Berikut uraiannya.

\section{Resistensi terhadap KDRT}

Resistensi perempuan terhadap laki-laki dalam novel Jalan Panjang Menuju Pulang dilakukan Fatin terhadap suaminya dalam rangka untuk mempertahankan hak asuh anak. Fatin tidak rela anaknya, yakni Ridho, dikuasai hak asuhnya oleh suaminya, yakni Rimbong. Fatin merasa ada pengingkaran terhadap komitmen dalam berumah tangga. Motivasi yang melenceng dari komitmen dalam membangun harmoni hubungan kekeluargaan ditentang oleh Fatin. Bagi Fatin, Ridho adalah anak kandung yang harus diasuh bersama, dimiliki bersama, dan menjadi salah satu faktor pembangun kebahagiaan dalam kehidupan berumah tangga. Apabila Ridho diambil alih hak asuhnya oleh Rimbong, dan kemudian dibawa ke Jakarta untuk tinggal bersama Rimbong, sedangkan Fatin tinggal di Lombok Barat sendirian tanpa 
ditemani anak semata-wayangnya, bukanlah suatu kebahagiaan, melainkan penderitaan. Oleh karena itu, apa pun yang terjadi, Fatin tetap mempertahankan Ridho dalam rengkuhannya. Data berikut dapat menggambarkan hal tersebut.

"Apa masih kurang semua harta kekayaan yang telah kuberikan kepadamu ini, Sayang? Semuanya untuk kamu. Aku hanya minta anakku dalam pengasuhanku!"

"Tidak bisa, tidak bisa! Takkan pernah kuberikan kepada siapa pun."

"Aku ayah kandungnya!"

"Ya, dan aku ibu kandung yang telah melahirkannya!"

Rimbong terus memaksanya agar menyerahkan hak asuh Ridho kepadanya. Fatin bersikukuh mempertahankan si kecil. (JPMP:88).

Data berupa dialog antara Fatin dan Rimbong tersebut menunjukkan perlawanan Fatin kepada suaminya yang ingin menguasai anak mereka. Fatin merasa diingkari dengan niat suaminya tersebut. Dalam konteks realitas sosial, fenomena semacam itu menjadi refleksi betapa perempuan tidak lagi hanya bersikap pasif manakala mendapatkan perlakuan yang tidak adil oleh laki-laki, termasuk suaminya.

\section{Resistensi terhadap Kekerasan Seksual}

Resistensi terhadap kekerasan seksual dalam novel Jalan Panjang Menuju Pulang dilakukan Fatin kepada Frankie. Fatin telah sering mendapat perlakuan tidak manusiawi dari Frankie, baik terkait dengan kekerasan fisik, berupa kekerasan seksual dan pelecehan seksual, maupun kekerasan psikis. Fatin menjadi objek, sedangkan Frankie menjadi subjek. Kekuatan fisik Fatin sebagai perempuan cenderung kalah dibandingkan Frankie, apalagi Frankie adalah lelaki Eropa. Meskipun demikian, Fatin berupaya melakukan perlawanan, baik perlawanan secara fisik maupun melalui jalur hukum. Resistensi secara fisik dilakukan Fatin karena dirinya sudah tidak tahan dengan penderitaan fisik yang dialaminya. Dirinya berupaya untuk memberanikan diri melakukan perlawanan kepada Frankie. Dirinya berpikir bahwa apa pun yang terjadi, yang penting harus melawan. Data berikut memberi gambaran tentang perlawanan fisik yang dilakukan Fatin kepada Frankie, terkait dengan kekerasan seksual yang telah dialami Fatin.

Inilah pertama kalinya Fatin melakukan perlawanan hebat disaksikan langsung oleh anaknya semata wayang. Selama ini peperang selalu berlangsung di dalam kamar, didominasi oleh si jahanam. Fatin berlari dan berhasil meraih pisau besar dari dapur. Ia pun sukses melindungi si kecil dari jangkauan lelaki yang mulai tampak mundur dan cemas (JPMP:146).

Kutipan data tersebut memberi gambaran bahwa keberanian Fatin muncul ketika dirinya dalam kondisi terdesak. Perlawanan dilakukannya meskipun dirinya tidak tahu apakah berhasil atau tidak. Perlawanan menjadi respons dari dalam dirinya atas dominasi laki-laki terhadap tubuhnya. Artinya, kekerasan fisik dibalas dengan perlawanan fisik.

Di sisi lain, Fatin juga melakukan perlawanan melalui jalur hukum, yakni melaporkan perbuatan Frankie kepada polisi. Resistensi semacam ini dilakukan oleh Fatin dengan harapan bukan hanya fisik yang menjadi fokus respons melainkan ranah yang lebih besar atau luas. 
Upaya resistensi Fatin memang tidak mudah karena dalam dunia hukum harus ada bukti-bukti material yang meyakinkan sehingga perangkat hukum baru dapat meyakini bahwa laporan tersebut dapat diakomodari. Meskipun demikian, tekad kuat Fatin menjadi semangat bagi dirinya untuk mengungkapkan kebenaran sejati, apalagi tekad tersebut mendapat dukungan dari keluarga Dominee Hartland yang selama ini membantu dalam kehidupan Fatin. Berikut data pendukungnya.

Beberapa hari kemudian, pengacara keluarga memberi kabar kepada Dominee Hartland. "Fatin Amar tidak perlu melepas kewarganegaraannya, karena bukti-bukti cukup kuat untuk menuntut balik si Frankie." Hatta, pihak kepolisian menemukan rekaman CCTV di sekitar apartemen Frankie. Sebagian peristiwa kekejaman lelaki itu terekam dengan jelas (JPMP:191).

Kutipan data tersebut memberi gambaran bahwa Fatin tidak hanya diam dengan ancaman Frankie. Ia juga melaporkan ke polisi atas perbuatan penganiayaan dan Keluarga Dominee Hartland yang selama ini menolongnya juga ingin membantu Fatin melawan lakilaki maniak seks tersebut. Fatin tidak hanya diam menghadapi ancaman, tetapi juga melaporkan ke polisi atas perbuatan penganiayaan dan kekerasan seksual. Polisi juga melakukan penyelidikan dan mencari bukti untuk menangkap Frankie. Rekaman di sekitar apartemen membuktikan bahwa Frankie telah melakukan tindak kriminal. Dengan demikian, upaya resistensi Fatin melalui jalur hukum berhasil dan Frankie dinyatakan bersalah sehingga masuk penjara.

Hasil analisis tentang dominasi laki-laki dan resistensi perempuan di atas menunjukkan sebagai refleksi atas realitas sosial. Fenomena sosial semacam itu hingga saat ini masih marak bahwa laki-laki cenderung merasa superordinat sehingga bertindak sesuai dengan kemauan dan kehendaknya, yakni menindas perempuan dengan cara kekerasan, baik terkait fisik maupun psikis. Di sisi lain, perempuan menyadari bahwa dirinya perlu mengekspresikan diri, bukan sekedar objek bagi laki-laki. Dalam konteks feminisme radikal, ekspresi perempuan berimplikasi dengan eksistensi tubuhnya. Artinya, tubuh perempuan merupakan aktualisasi diri dari dirinya. Tafsir terkait dengan isi novel Jalan Panjang Menuju Pulang bahwa Fatin sebagai perempuan yang "utuh" bukan sekedar menjadi objek dari lakilaki, termasuk laki-laki yang menjadi suaminya. Fatin merasa sejajar dengan laki-laki, sehingga tubuhnya bukan sekedar fisik yang boleh dipermainkan oleh laki-laki. Tubuhnya adalah citra dirinya, sehingga perlakuan dari laki-laki atas tubuh tersebut harus atas dasar persetujuan dari dirinya dengan dasar relasi kesetaraan.

\section{SIMPULAN}

Karakteristik masyarakat patriarki masih menunjukkan fenomena dominasi laki-laki atas perempuan. Laki-laki merasa superordinat, sedangkan perempuan dianggap subordinat. Dominasi laki-laki terhadap perempuan dalam novel Jalan Panjang Menuju Pulang berupa kekerasan fisik, kekerasan psikis, dan kekerasan dalam rumah tangga (KDRT). Representasi yang menyiratkan makna dan ideologi sebagai simbol perlawanan atau resistensi kaum tertindas atas segala penindasan atau penjajahan dilakukan oleh Fatin. Ia melakukan resistensi terhadap kekerasan seksual dan KDRT. Resistensi terhadap kekerasan seksual dilakukan Fatin yakni melakukan perlawanan dalam peristiwa di apartemen dan dapat melaporkan Frankie 
kepada pihak kepolisian untuk mendapatkan hukuman setimpal. Resistensi terhadap KDRT dilakukan Fatin dengan cara melawan kepada suaminya dan membawa lari anaknya agar berada dalam kekuasaannya. Dalam konteks feminisme radikal, ekspresi perempuan berimplikasi dengan eksistensi tubuhnya. Artinya, tubuh perempuan merupakan aktualisasi diri dari dirinya. Tafsir terkait dengan isi novel bahwa Fatin sebagai perempuan yang "utuh" bukan sekedar menjadi objek dari laki-laki, termasuk laki-laki yang menjadi suaminya. Tubuh adalah citra diri, sehingga perlakuan dari laki-laki atas tubuh tersebut harus atas dasar persetujuan dari dirinya dengan dasar relasi kesetaraan.

\section{DAFTAR PUSTAKA}

Abrams, M.H. 1981. A Glossary of Literary Terms. New York: Harcourt, Brace 7 World, Inc.

Anoegrajekti, N. 2010. Identitas Gender: Kontestasi Perempuan Seni Tradisi. Jember: Kelompok Peduli Budaya dan Wisata Daerah Jawa Timur.

Fakih, M. 2001. Analisis Gender dan Transformasi Sosial. Yogyakarta: Pustaka Pelajar.

Khalilurrahman, A. 2017. “Jalan Panjang Petualang”. http://mediajatim.com/2017/11/29/jalan-panjang-petualang/. (diakses 20 November 2018).

Nurjanah, T. 2018. "Analisis Ikon, Indeks, dan Simbol dalam Novel Jalan Panjang Menuju Pulang Karya Pipiet Senja". https://akademik.unsoed.ac.id/index.php?r=artikelilmiah/view\&id=21576. (diakses 20 November 2018).

Putri, R.M. 2018. "Motivasi pada Tokoh Utama dalam Novel Jalan Panjang Menuju Pulang Karya Pipiet Senja: Tinjauan Psikologi Sastra dan Implikasinya terhadap Pembelajaran Sastra di SMA”. http://lib.unj.ac.id/tugasakhir/index.php?p=show_detail\&id=57095\&keywords=. (diakses 20 November 2018).

Resti, P. 2019. “Kekerasan terhadap Perempuan dalam Novel Jalan Panjang Menuju Pulang Karya Pipiet Senja.” Skripsi. Sumbar: STKIP PGRI Sumbar.

Rosliani, A. 2018. "Review Book Karya Pipiet Senja Jalan Panjang Menuju Pulang”. http://amelsastra.blogspot.com/2018/01/review-novel-pipiet-senjajalan-panjang.html. (diakses 20 November 2018).

Senja, P. 2017. Jalan Panjang Menuju Pulang. Jakarta: Republika Penerbit.

Tong, R. P. 1998. Feminist Thought: Pengantar Paling Komprehensif kepada Aliran Utama Pemikiran Feminis. Yogyakarta: Jalasutra. 